Отримано: 9.11.2020 p.

Прорецензовано: 20.11.2020 p.

Прийнято до друку: 26.11.2020 p.

e-mail: ishchenko@nas.gov.ua

DOI: $10.25264 / 2409-6806-2020-31-151-156$
Іщенко О. Україна й українці на сторінках «Австралійської енциклопедії.. Наукові записки Національного університету «Острозька академія». Серія «Історичні науки». Острог, 2020. Вип. 31. С. 151-156.

\title{
Олександр Іщценко
}

\section{УКРАЇНА Й УКРАЇНЦІ НА СТОРІНКАХ «АВСТРАЛІЙСЬКОЇ ЕНЦИКЛОПЕДІЇ»}

\begin{abstract}
У статті подано аналіз 10-ти томної «Австралійської енциклопедї», опублікованої 1958 року, з метою виявлення інформачії, що стосується тих чи тих питань, пов'язаних з украйнським народом. 3'ясовано, щзо основний масив інформації про украӥнців - ие статистичні відомості про украйнську громаду в Австралії, яка оселилася після Другої світової війни. Серед 10 томів не зафіксовано жодних даних про Україну, ї столицю, визначних діячів украӥнського народу тощо. Подано також загальну характеристику австралійської енциклопедистики.
\end{abstract}

Ключові слова: «Австралійська енциклопедія», Австралія, енциклопедистика, діаспора.

\section{Oleksandr Ishchenko}

\section{THE COVERAGE OF UKRAINE AND UKRAINIANS IN THE AUSTRALIAN ENCYCLOPEDIA}

In this article, we present an analysis of the 10-volumed Australian Encyclopedia published in 1958. The purpose of the analysis is to identify encyclopedic information concerning the Ukrainian people. Since the late 19 th century, a part of the Ukrainian ethnic group inhabits the Australian continent, so it is natural to expect the appearance of Ukrainians in encyclopedic publications of Australia. But do Australians mention Ukrainians in their own fundamental encyclopedias? This question is caused not only by the general interest, but also by the fact that Ukraine is shown in the national narratives of many countries through various myths generated by Soviet propaganda. Therefore, the analysis of the representation of Ukrainians in the pages of foreign encyclopedias is a topical issue of contemporary Ukrainian studies in general. In this study, we found that the main body of information about Ukrainians is statistical data about the Ukrainian community in Australia, which settled after the Second World War. Among the 10 volumes there are no mentions of Ukraine, its capital, prominent people of the nation, etc. In addition, general highlights of the Australian encyclopedia publishing sphere are proposed. It is noted that the Australian Encyclopedia as a fundamental work published in six editions during 1925-1996 is the main achievement of the Australian encyclopediography. It is noteworthy that there is currently no national online encyclopedia in Australia. At the same time, there are domain (subject-specific) publications by research teams among other achievements of contemporary Australian encyclopedia publishing, such as the Encyclopaedia of Aboriginal Australia, the Historical Encyclopedia of Western Australia, the Companion to Tasmanian History, etc.

Key words: Australian encyclopedia, Australia, encyclopedia studies, diaspora.

Студії із зарубіжної енциклопедистики українські науковці найчастіше присвячують класичним виданням універсального характеру, відомим у всьому світі - «Британіка», «Американа», німецька енциклопедія «Брокгауз», французькі «Ларусса», «Універсаліс», «Енциклопедія» Дідро та Д' Аламбера тощо - напр., див. [1]. Однак сьогодні, в часи популярності «Вікіпедії», в різних країнах набувають актуальності національні енциклопедії, орієнтовані на представлення, виокремлення й збереження інформації про народи, їх історію, культурні надбання, традиції, територіальні особливості тощо. Одна з основних цьому причин - глобальне поширення явищ дезінформації, що зумовлює потребу в надійних джерелах енциклопедичних знань. 3 огляду на це вважаємо необхідними дослідження історії та сучасного стану енциклопедичної справи в різних країнах Європи та світу загалом. 
Об’єкт нашої розвідки - національна енциклопедистика Австралії, яка досі не була в полі зору українських фахівців. Австралійський континент $є$ місцем проживання частини українського етносу, тож цілком закономірно очікувати фігурування українства в енциклопедичних виданнях Австралії. 3'ясувати, якою мірою українці та явища, пов'язані з Україною, висвітлені на сторінках австралійських енциклопедій (зокрема, «Австралійської енциклопедії»), є метою цього дослідження.

Зауважимо, що існує чимало українських видань, зокрема й довідкових і енциклопедичних, які присвячено українській діаспорі в Австралії. Серед них - «Українці Австралії. Енциклопедичний довідник» [10], четвертий том «Енциклопедії української діаспори» [4], довідники «Українці в Австралії» [11], «Українська Австраліана» [7]. Інститут всесвітньої історії НАН України 2017 року започаткував енциклопедичне видання «Країни світу й Україна», в одному з майбутніх томів якого заплановано представити Австралію.

Та чи згадують про українців австралійці у власних фундаментальних енциклопедіях? Це питання викликано не лише загальним інтересом, а й тим фактом, що Україна у національних наративах багатьох держав світу постає крізь призму різноманітних міфів, породжених радянською пропагандою. Тож аналіз представленості українців на сторінках зарубіжних енциклопедій $є$ актуальним питанням сучасних українознавчих студій загалом.

Розвідку виконано на матеріалі 5-го видання англомовної 10-томної «Австралійської енциклопедії», опублікованої 1958 року [14]. Це той період, коли України не існувало на геополітичній карті світу як окремої незалежної держави, що дає можливість припускати про низьку ймовірність у зазначеному виданні появи таких слів, як «Україна», «українець», «український» тощо, як і загалом представлення українських персоналій, явищ безвідносно до їхнього найменування. До того ж треба зауважити, що середина XX ст. - це час, коли українці лише почали мігрувати до Австралії й не встигли виявити себе на цьому континенті тією мірою, аби потрапляти на сторінки енциклопедичних видань. Ці два аргументи лише додають нашій розвідці непередбаченості й цікавості щодо результатів.

Зміст дослідження полягав у пошуку за ключовими словами статей енциклопедії. Згадування про Україну й українців виявляли шляхом автоматизованого пошуку відповідного матеріалу за етнонімом «Ukraine» і його похідним «Ukrainian», екзонімами «Rus», «Ruthenia» і їх похідними «Kievan Rus», «Halychian Rus», «Volhynian Rus», «Carpathian Rus», «Ruthenian», а також топонімами «Куіv» / «Kiev», «Lviv», прізвищем «Shevchenko». Пошук реалізовано 3 допомогою електронної копії 10 томів енциклопедії на сайті Бібліотеки «HathiTrust» ${ }^{1}$.

Основний здобуток австралійської енциклопедистики - фундаментальне видання під назвою «Австралійська енциклопедія» (The Australian Encyclopaedia), що витримала шість перевидань упродовж 1925-1996 років. Перше видання складалося з двох томів (1925-1926), друге, що перебуває у фокусі нашої уваги, - $з$ десяти (1958), третє - із шести (1977), четверте - із дванадцяти (1983), п’яте - із дев'яти (1988) і шосте - з восьми томів (1996). Всі томи кожного перевидання були опубліковані впродовж одного року, хоча їхня підготовка, звісно, займала значно триваліший період. Наприклад, робота, що втілилася у два томи першого видання енциклопедії, була започаткована за 13 років до їхньої появи. А 10 томів, оприлюднених 1958 року, почали укладати 1947 року. Саме з появою другого видання енциклопедія набула популярності в суспільстві - «газети по всій країні публікували огляди 3 яскравими заголовками, називаючи енциклопедію не лише корисним довідковим джерелом, а й маркером культурної зрілості Австралії» [12, с. 17].

Як зазначає біограф Р. МакГрегор, А. Чисхолм, головний редактор другого видання енциклопедії, намагався долучати до неї якомога більше об'єктів культури, фольклору, етнографії, топографії, аби зобразити дух Австралії, сформувати образ країни і народу. Йому вдалося створити енциклопедію, яка не лише акумулювала факти про Австралію, а й слугувала квінтесенцією австралійськості. Національна зорієнтованість видання зробила його популярним в австралійському соціумі [12, с. 18]. Очевидно, це надихнуло Літературну спілку вдатися до створення подібного нового видання - «Нової національної австралійської енциклопедії» [13], яку світ побачив 1974 року в двох томах.

Прикметно, що нині в Австралії не існує національної онлайн-енциклопедії. Водночас серед інших здобутків сучасної австралійської енциклопедистики - видання вужчого спрямування, підготовлені науковими колективами. Так, Австралійський інститут корінних народів та населення островів Торресової протоки видав «Енциклопедію аборигенів Австралії» [16], Центр історичних досліджень

${ }^{1}$ Див. URL: https://catalog.hathitrust.org/Record/001268021. 
Університету Тасманії - енциклопедичне видання «Путівник тасманською історією» [15], Університет Західної Австралії - «Історичну енциклопедію Західної Австралії» [17]. Існує низка й інших галузевих енциклопедичних видань.

Далі окреслимо представленість українства на сторінках енциклопедичних видань Австралії на прикладі «Австралійської енциклопедії» другого видання, яке готувалося в період від 1947 до 1958 років, коли українці активно прибували до цісї країни.

Простеживши всі статті з 10-ти томів за ключовими словами, зазначеним вище, виявили лише поодинокі випадки їх вживання. Матеріали, що стосуються українців, було віднайдено за двома ключовими словами - «Ukraine» i «Ukrainian». Схарактеризуємо віднайдені статті згідно з нумерацією томів (прикметно, що не в кожному томі знайдено відповідні статті).

Том 1. На початку першого тому подано розділ з переліком тих людей, які долучилися до підготовки енциклопедичних матеріалів. В енциклопедії статті не містять відомостей, хто їх підготував, однак авторів згадано окремим відповідним розділом. У ньому зазначено Степана Григоровича Процюка ${ }^{2}$ (Stefan George Prociuk) - члена редколегії «Енциклопедії українознавства». Цікаво, що англійською мовою українську енциклопедію названо як «Ukrainian Encyclopaedia» (вочевидь за зразком до «Australian Encyclopaedia»), натомість нині усталеним перекладом цієї праці англійською мовою $\epsilon$ «Encyclopedia of Ukraine». Закономірно припустити, що С. Процюк відповідав за українознавчий матеріал. Однак, будучи фахівцем з машино- й авіабудування, міг долучитися й до підготовки низки інших, наприклад, такої розлогої статті, як «Авіація» [14, т. 1, с. 341-466], що займає понад 100 сторінок у першому томі (власне, ця стаття поділена на низку різних, що об'єднані спільною темою).

Tом 2. У другому томі вміщено статтю під назвою «Conrad in Australia» про Джозефа Конрада, відомого як Юзеф Теодор Конрад Коженьовський. В енциклопедії зазначено, що народився у родині поляків в Україні, згодом виїхав у Англію, ставши ії громадянином. Цитуємо перші речення в оригіналі англійською мовою: «Joseph Conrad (1857-1924), whose full name was Teodor Jozef Konrad Korzeniowski, was born of Polish parents in the Ukraine. He became a sailor, and in 1884 was naturalized as a British subject. His novels and stories about the sea, all of them written in English, are unrivalled of their kind» [14, т. 2, c. 501].

Для порівняння, в «Енциклопедії Сучасної України» подано такі початкові відомості про персоналію: «КО́НРАД Джозеф (Conrad Joseph; справж. - Коженьовський Теодор-Юзеф-Конрад; 03.12.1857, с. Терехове, нині Бердичів. р-ну Житомир. обл. -03.08.1924, м. Бішопсборн, Велика Британія) - англійський письменник, критик польського походження» [3, с. 321-322]. В «Енциклопедії історії України» таке: «КО́НРАД (Сопrad) Джозеф (справжні ім'я та прізв. - Юзеф-Теодор-Конрад Коженьовськи; 03.12.1857-03.08.1924) - класик англійської літератури (мариніст, літературний критик)» [2, с. 37-38].

Зіставляючи стиль викладу матеріалу про Дж. Конрада в австралійській та українських енциклопедіях, впадає в око академізм формулювань («англійський письменник», «класик англійської літератури», «мариніст» тощо) в «Енциклопедії Сучасної України» й «Енциклопедії історії України» і наведення лише фактів та уникненням визначень в «Австралійській енциклопедії». Австралійська стаття не містить дефініції, а лише наводить дані. Цим австралійська енциклопедія відрізняється від сучасних видань, зокрема й українських, у яких дефініція слугує важливим структурним елементом енциклопедичних статей - як загальних, так і біографічних. У цьому сенсі з усіх українських енциклопедій стилістично найближчими до «Австралійської енциклопедії» $є$ «Українська загальна енциклопедія» та вже згадана «Енциклопедія українознавства», що свідчить про схожість загальних принципів побудови енциклопедичних статей у ті часи (перша половина й середина XX ст.). Ось що можна зазначити про стилістично-типографічні особливості австралійської енциклопедії: назву статей, тобто гасла надруковано заголовними літерами; на цьому ж рядку через кому подається виклад статті; чіткі дефініції відсутні; стаття являє собою послідовність фактів та їхній опис; у кінці статті - перелік основної літератури (подано шрифтом меншого розміру порівняно з основним матеріалом статті); розлогі статті можуть бути поділені на розділи (зазначаються назви розділів); скорочення

\footnotetext{
${ }^{2}$ Процюк Степан (03.01.1916 - 12.10.1984) - економіст, інженер авіації. Здобув освіту у Львівській політехніці. У 1950 1957 роках мешкав в Австралії, працюючи інженером в машинобудівельній галузі. Від 1957 року жив у США, де працював у галузі літакобудування. Член НТШ, УВАН, багатьох американських наукових товариств, редактор «Вістей української інженерії», «Енциклопедії українознавства» [6, т. 1, с. 312].
} 
відсутні (характерно для всіх англомовних видань - не лише того періоду, а й пізнішого, коли скорочення набули поширення у виданнях радянської доби).

Том 6. У шостому томі є стаття «Натуралізація» [14, т. 6, с. 255-256], що висвітлює процес надання іноземцям громадянства Австралії. У ній згадано про українців в Австралії, зокрема, зазначено, що у 1955 році громадянство Австралії отримали 624 українці. Між іншим, ця стаття наводить 44 національності й дані щодо кількості натуралізованих їх представників. Скажімо, кількість поляків, які отримали громадянство 1955 року, - 3229 (найбільше зі всього переліку), росіян - 286, білорусів - 11, латвійців - 1288, литовців - 519.

Том 7. У великій статті «Населення» [14, т. 7, с. 188-195], крім іншого, є інформація про представників різних національностей в Австралії. Так, в одній із таблиць, поданій на 192-й сторінці, показано кількість австралійських іммігрантів у країні станом на 1947 і 1954 роки. У ній згадано й про українців, зокрема констатовано, що в 1954 році в Австралії зафіксовано 14756 осіб, які народилися в Україні (за 1947 рік даних щодо українців немає).

У сьомому томі вміщено статтю «Росіяни в Австралії» [14, т. 7, с. 526-528], що містить згадку про українців. Вона повторює дані про кількість українських іммігрантів, зафіксованих у переписі населення Австралії 1954 року. Однак тут подано інші цікаві відомості: стверджується, що народжених у Росії іммігрантів було 13098 осіб, народжених в Україні - 14756 осіб, при цьому кількість тих, хто вважав себе росіянином, було лише 4256, а тих, хто називав себе представником української національності, - 17 234. Дослідники історії української еміграції таку ситуацію пояснюють так: «Характерною рисою першої хвилі вітчизняної еміграції на п’ятий континент було те, що вона походила не безпосередньо з України, а брала витоки переважно з території Росії. На відміну від західних українців, яким у пошуках землі й роботи доводилося емігрувати за океан, безземельні українці з Наддніпрянщини мігрували на схід Російської імперії. < .. > Практично вся українська еміграція в Австралії складалася з робітників і селян, які приїхали сюди з Далекого Сходу, Південного Сибіру і Китайсько-Східної залізниці» [8, с. 152].

Між іншим, як зазначає М. Чорномаз, досліджуючи українців, які оселилися на Далекому Сході, «у першій половині 20 ст. почалися процеси русифікації емігрованих українців (йдеться про Зелений Клин): царський уряд не визнавав українців за окремий народ, тому в офіційній статистиці до 1917 року українці включалися в графу “росіяни”» [5, с. 10]. Однак, українцям, які з тих земель потрапляли до Австралії, не стало на заваді ідентифікувати себе представниками українського етносу під час перепису населення Австралії, про що свідчить «Австралійська енциклопедія». Очевидно, збереженню української самобутності переселенців сприяла передусім компактність їхнього розселення.

Том 9. У дев’ятому томі подано невелику статтю «Українці в Австралії» [14, т. 9, с. 68-69]. У ній зазначено, що українці - одна з наймолодших національних громад цієї країни, яка активно заселялася в період 1948-1951 років. Інформація про населення містить згадані вище дані перепису 1954 року (14 756 осіб, які прибули з території України, і 17234 осіб, які вважали себе українцями за національністю). У статті йдеться про громадсько-політичне життя української громади, окреслено створення й дію Федеральної української ради (Federal Ukrainian Council), яка прагнула відновлення незалежності України; культурну (українські театри у Сіднеї й Мельбурні), наукову (австралійські осередки Української вільної академії наук та Наукового товариства імені Шевченка), гендерно зорієнтовану (Союз українок Австралії) діяльність українців.

Інших відомостей про українців і Україну на сторінках цієї енциклопедії не знайдено. Як бачимо, більшість зафіксованих згадок стосуються статистичного опису української громади в Австралії, що оселилася після Другої світової війни. Отже, австралійський читач, який захоче отримати відомості про Україну, мало що знайде у ній. Видання не подає відомостей про столицю України, визначних діячів культури, науки.

Цей факт спричинив поглиблення нашого аналізу: ми оглянули всі статті першого тому й переконалися у відсутності в енциклопедії подання окремих статей про країни і їхні столиці. Отже, концепція видання не передбачала окремого висвітлення на сторінках енциклопедії інших народів і держав. Гадаємо, це зумовлено не так австралоцентризмом енциклопедії, як відсутністю в ті роки того ступеня глобалізації світу, який маємо сьогодні. Нині національні енциклопедії, що ставлять за мету представити етнічні особливості, історію, географію, культурні надбання того чи того народу, не нехтують поданням загальної інформації про країни світу, передусім ті, з якими сформувалися 
тісні контакти. Загалом, як стверджують дослідники, «сучасна глобалізація світу є взаємозалежністю країн та народів, що зумовлює як загальний прогрес, так і нові загрози» [9, с. 126]. У середині XX століття такої виразної взаємозалежності між країнами ще не існувало, що й позначалося на реєстрі гасел національних енциклопедичних видань.

Основний масив довідкової інформації про українських мігрантів в Австралії можна віднайти в українськомовних виданнях, про що зазначено на початку статті. Щоправда, М. Павлишин, аналізуючи стан досліджень про українців в Австралії, звертає увагу на те, що відомості про український етнос можуть бути неточні у тих джерелах, які укладалися тамтешньою українською діаспорою: «Інформація, яка в них зафіксована, стосується передовсім українських емігрантів, що прибули до Австралії після Другої світової війни, їхніх нащадків, та організацій, які ця громада створила: церковних, громадських, культурно-мистецьких, освітніх, молодіжних, жіночих, кооперативних, ветеранських, політичних, спортивних. Тільки в окремих випадках статті й гасла в цих виданнях базувалися на незалежних дослідженнях. Як правило, редколегії використовували інформації, які організації та особи самі про себе подали» [6, с. 171].

3 іншого боку, укладачі «Австралійської енциклопедії», описуючи українських іммігрантів, окрім даних перепису населення, могли користатися й іншими достовірними джерелами, однак цього, вочевидь, не робили або ж не вважали відповідну інформацію за потрібну в енциклопедії. Йдеться про австралійські архіви, що, як стверджують дослідники, «містять багато даних про українських переселенців у період кінця XIX - початку XX ст.; ці матеріали проливають світло і на особливості їх розселення по континенту» [8, с. 154-155]. Однак таких відомостей енциклопедія не подає.

Здійснивши аналіз десяти томів «Австралійської енциклопедії», опублікованої 1958 року, на предмет виявлення інформації, пов'язаної з українцями й Україною, з'ясували таке.

1. Австралійське видання містить спорадичні дані про українців (у 1-му, 2-му, 6-му, 7-му і 9-му томах), передусім тих, що мешкали в Австралії. Довідки про Україну, столицю, визначних діячів нації тощо відсутні. Це пов'язано з концепцією видання - на його сторінках немає статей про країни і міста світу.

2. Основний масив інформації про українців - це статистичні відомості про українську громаду в Австралії, яка оселилася після Другої світової війни (частково інформація повторюється в різних статтях).

3. Незважаючи на наявність в Австралії архівних документів, що містять інформацію про українців, заселених до Другої світової війни (отже, ними могли скористатися укладачі «Австралійської енциклопедії»), цих відомостей у виданні немає.

4. За стилем оформлення статей енциклопедія відрізняється від сучасних, однак нагадує українські видання тих часів, зокрема «Українську загальну енциклопедію» та «Енциклопедію українознавства».

Список використаних джерел та літератури:

1. Воронка Г. Історія довідкових видань Європи та України. Молодий вчений. 2015. № 5. С. 162-168.

2. Енциклопедія історії України. Т. 5 / гол. редкол.: В.А. Смолій; Інститут історії України НАН України. Київ, 2008. 560 с.

3. Енциклопедія Сучасної України. Т. 14 / гол. редкол.: І. Дзюба, А. Жуковський, М. Железняк та ін.; Інститут енциклопедичних досліджень НАН України. Київ, 2014. 706 с.

4. Енциклопедія Української Діяспори: у 7 т. / гол. ред. В. Маркусь; Наукове Товариство ім. Шевченка, Національна Академія Наук України. Київ, Нью-Йорк, Чикаго, Мельбурн, 1995-2012.

5. Зелений Клин. Енциклопедичний довідник / укл. В. Чорномаз. Владивосток: Далекосхідний федеральний університет, 2011.288 с

6. Павлишин М. Українці в Австралії: стан досліджень. Наукові записки Начіонального університету «Острозька академія»: Історичні науки. 2008. Вип. 11. С. 171-181.

7. Панченко О. Українська Австраліана: Полтавщина, Галичина, Боснія. Київ: Вид-во ім. Олени Теліги, 2014. $383 \mathrm{c}$.

8. Савченко О. Витоки української еміграції в Австралію. Українська орієнталістика. 2010. Вип. 4-5. C. $151-158$.

9. Самойлов О. Поняття глобалізації, ії сутність та теоретичні підходи. Проблеми міжнародних відносин. 2015. Вип. 10-11. С. $125-141$.

10. Українці Австралії: Енциклопедичний довідник / Товариство збереження української спадщини в Австралії. Сідней: «Вільна думка», 2001. 673 с.

11. Українці в Австралії: у 2-х т. Мельбурн: Союз Українських Організацій Австралії, 1966-1998.

12. McGregor R. Encyclopaedia for a Nation. SL Magazine. 2017. 10 (2). P. 16-19. 
13. New National Australian Encyclopaedia. Vol. 1-2 / National Literary Association. Sydney: National Literary Association, 1974.

14. The Australian Encyclopaedia. Vol. 1-10 / ed. A.H. Chisholm. Sydney, 1958.

15. The Companion to Tasmanian History / ed. A. Alison; Centre for Historical Studies, University of Tasmania. Hobart, 2006. 568 p.

16. The Encyclopaedia of Aboriginal Australia: Aboriginal and Torres Strait Islander History, Society and Culture / ed. D. Horton; Australian Institute of Aboriginal and Torres Strait Islander Studies. Canberra: Aboriginal Studies Press, 1994. 1340 p.

17. The Historical Encyclopedia of Western Australia / eds. J. Gregory, J. Gothard, J. Gregory, J. Gothard; Centre for Western Australian History, the University of Western Australia. Perth: University of Western Australia Press, 2009. $691 \mathrm{p}$

\section{References}

1. Voronka H. Istoriia dovidkovykh vydan Yevropy ta Ukrainy. Molodyi vchenyi. 2015. № 5. S. 162-168.

2. Entsyklopediia istorii Ukrainy. T. 5 / hol. redkol.: V.A. Smolii; Instytut istorii Ukrainy NAN Ukrainy. Kyiv, 2008. $560 \mathrm{c}$.

3. Entsyklopediia Suchasnoi Ukrainy. T. 14 / hol. redkol.: I. Dziuba, A. Zhukovskyi, M. Zhelezniak ta in.; Instytut entsyklopedychnykh doslidzhen NAN Ukrainy. Kyiv, 2014. $706 \mathrm{~s}$.

4. Entsyklopediia Ukrainskoi Diiaspory: u 7 t. / hol. red. V. Markus; Naukove Tovarystvo im. Shevchenka, Natsionalna Akademiia Nauk Ukrainy. Kyiv; Niu-York; Chykaho; Melburn:1995-2012.

5. Zelenyi Klyn. Entsyklopedychnyi dovidnyk / ukl. V. Chornomaz. Vladyvostok: Dalekoskhidnyi federalnyi universytet, 2011. $288 \mathrm{~s}$.

6. Pavlyshyn M. Ukraintsi v Avstralii: stan doslidzhen. Naukovi zapysky Natsionalnoho universytetu «Ostrozka akademiia»: Istorychni nauky. 2008. Vyp. 11. S. 171-181.

7. Panchenko O. Ukrainska Avstraliana: Poltavshchyna, Halychyna, Bosniia. Kyiv: Vyd-vo im. Oleny Telihy, 2014. $383 \mathrm{~s}$.

8. Savchenko O. Vytoky ukrainskoi emihratsii v Avstraliiu. Ukrainska oriientalistyka. 2010. Vyp. 4-5. S. 151-158.

9. Samoilov O. Poniattia hlobalizatsii, yii sutnist ta teoretychni pidkhody. Problemy mizhnarodnykh vidnosyn. 2015. Vyp. 10-11. S. 125-141.

10. Ukraintsi Avstralii: Entsyklopedychnyi dovidnyk / Tovarystvo zberezhennia ukrainskoi spadshchyny v Avstralii. Sidnei: «Vilna dumka», 2001. $673 \mathrm{~s}$

11. Ukraintsi v Avstralii: u 2-kh t. Melburn: Coiuz Ukrainskykh Orhanizatsii Avstralii, 1966-1998.

12. McGregor R. Encyclopaedia for a Nation. SL Magazine. 2017. 10 (2). P. 16-19.

13. New National Australian Encyclopaedia. Vol. 1-2 / National Literary Association. Sydney: National Literary Association, 1974

14. The Australian Encyclopaedia. Vol. 1-10 / ed. A.H. Chisholm. Sydney, 1958

15. The Companion to Tasmanian History / ed. A. Alison; Centre for Historical Studies, University of Tasmania. Hobart, 2006. $568 \mathrm{p}$

16. The Encyclopaedia of Aboriginal Australia: Aboriginal and Torres Strait Islander History, Society and Culture / ed. D. Horton; Australian Institute of Aboriginal and Torres Strait Islander Studies. Canberra: Aboriginal Studies Press, 1994. $1340 \mathrm{p}$.

17. The Historical Encyclopedia of Western Australia / eds. J. Gregory, J. Gothard, J. Gregory, J. Gothard; Centre for Western Australian History, the University of Western Australia. Perth: University of Western Australia Press, 2009. $691 \mathrm{p}$ 